\title{
Earnings Management as a Tool of Bankruptcy Prevention during Global Pandemic of COVID- 19
}

\author{
Mariana Usheva ${ }^{1}$, Ladislav Vagner ${ }^{2, *}$ \\ ${ }^{1}$ South-West university "Neofit Rilski", Faculty of economics, Department "Management and \\ marketing", Ivan Mihailov 60, 2700 Blagoevgrad, Bulgaria \\ ${ }^{2}$ University of Zilina, Faculty of Operation and Economics of Transport and Communications, \\ Department of Economics, Univerzitna 1, 01026 Zilina, Slovakia
}

\begin{abstract}
.
Research background: The Covid-19 pandemic affects all areas of operation in almost every country, except for Slovakia. In Slovakia, radical measures were taken in the first phase of March, and the state of emergency required the closure of gastronomic establishments, service operations, restrictions on shops, stricter hygiene measures and restrictions on free cross-border as well as a national movement. The second phase is foreseen in the autumn, which should be much more demanding, and it will also be a great challenge for companies to be able to adapt their activities to the new standards. An important question for companies is how this will affect their financial results. Some companies were not affected by the disease; others had to be closed, did not generate any profit, eventually went bankrupt.

Purpose of the article: The purpose of this article is primarily to examine the impact of coronavirus on earnings management and how it will affect further decision-making within the company. In our study, we focused on the impact that Covid-19 has or will have on the management of companies in Slovakia. A total of 172 companies in Slovakia operating in various sectors were interviewed

Methods: The methodology used standard questionnaire survey procedures with scale answers. We addressed companies, despite the sector in which they operate. The overall return was $20 \%$, and we obtained 172 responses.

Findings \& Value added: Because the consequences of the Covid-19 disease are not yet evident, managers within earning management will also count on reserves in the form of savings accounts more than before.
\end{abstract}

Keywords: earnings management; IPA; performance; importance; COVID-19

JEL Classification: $G 33 ; B 26 ; D 25$

\footnotetext{
*Corresponding author: ladislav.vagner@,fpedas.uniza.sk
} 


\section{Introduction}

Succeeding in business leads business owners and leaders to think differently about money and resources. Creating savings makes it easier for a company to deal with worse times and thus avoid bankruptcy. Similar issues have been addressed by several authors, such as Fielden et al., [1]; Kliestik et al., [2]; Valaskova et al., [3]. Many business owners never break through their know-how about earnings management. However, leaders who want to develop a strong and robust company will make sensible decisions about all the resources of their business [4].

One of the goals that leaders should pursue is to build and maintain a healthy business savings account [5]. Thus, savings form the first category of this analysis. Many entrepreneurs never consider it essential to open a savings account and try to push the profit forward again. There are several reasons for setting up a savings account for a company. The most important thing is that the company is ready for unexpected changes in the environment.

A perfect example is a current situation in a world where many companies are suffering from the Covid-19 pandemic disease, which has led to and is closing companies, restricting cross-border trade due to border closures. The business environment is a profound concern for the state and institutions to make it encouraging to boost entrepreneurship [6]. Many companies, especially in the service and catering sectors, felt the consequences immediately. Some businesses have had to close down as a result of these persistent problems. Therefore, it is vital that companies also think about the savings account so that they are not negatively affected by the environmental situation. However, such an account, where the company accumulates funds for a long time, can also be used for projects of a longer-term nature, which are more complex and require high expenses. The implementation of projects allows the company to work and at the same time, can gain a competitive advantage [7].

Investment in research and development and earnings management means a two-way relationship. Research and development is a stimulus for earnings management as well as earnings management practices $[8,9]$. At the same time, $\mathrm{R} \& \mathrm{D}$-intensive companies have key discretionary factors and tools to increase discretion effectively. R\&D has a very high risk of failure due to its $R \& D$ characteristics and $R \& D$ accounting estimates [10]. However, little attention has been paid to this evidence, and most current research on R\&D manipulation focuses only on identifying the determinants of $R \& D$ accounting. Undoubtedly, research and development is a stimulus and a tool for earnings management [11]. It also represents another category in the analysis.

Investments in projects that could have been preceded by research are also close to research and innovation. These can be various projects of the company, whether in the form of a non-repayable financial contribution or a grant from calls announced by the EU. However, it can also be cross-border cooperation on projects.

Another category is intellectual capital, as it also has an impact on earnings management. In the knowledge economy, the success of organisations depends on the power of intellectual capital. Knowledge of intellectual capital is gaining in importance compared to other factors of production, such as land, capital and machinery. Thus, in this economy, the experience is considered the most critical element of production and is named as the most critical competitive advantage of organisations [12], i.e. the current and future success in competition between organisations mainly based on strategic knowledge management. From a strategic point of view, intellectual capital can be used to create and apply knowledge to increase the value of an organisation [13]. Intellectual capital is one of the modern concepts that is becoming increasingly important in terms of image and measurement [14]. Intellectual capital is a continually evolving and ever-changing concept 
due to the environment that surrounds it. Many companies misunderstand intellectual capital and its relationship in developing and improving quality. In recent years, after the bankruptcy of some of the world's largest companies, researchers and financial analysts, the quality of note income is an essential aspect in assessing an entity's financial health. Yet, it is often overlooked by investors, lenders and other users of financial statements [15].

Table 1. Brief literature overview of authors and publications according to the selected category

\begin{tabular}{|c|c|c|}
\hline Category & Publication & Author \\
\hline Savings & $\begin{array}{l}\text { Earnings management to exceed thresholds. } \\
\text { The role of loan loss provisions in earnings } \\
\text { management, capital management, and signaling: } \\
\text { The Spanish experience. } \\
\text { The effect of the compensation system on earnings } \\
\text { management and sustainability: Evidence from } \\
\text { Korea banks. }\end{array}$ & $\begin{array}{l}\text { Degeorge et al., } 1999 \\
\text { Anandarajan et al., } 2003 \\
\text { Lee \& Hwang, } 2019\end{array}$ \\
\hline Projects & $\begin{array}{l}\text { Does earnings management affect firms' investment } \\
\text { decisions? } \\
\text { Earnings management and corporate investment } \\
\text { efficiency: does the board of directors matter? } \\
\text { Earnings management, business strategy, and } \\
\text { bankruptcy risk: evidence from Indonesia. }\end{array}$ & $\begin{array}{l}\text { McNichols \& Stubben, } \\
2008 \\
\text { Bzeouich et al., } 2019 \\
\text { Agustia et al., } 2020\end{array}$ \\
\hline R\&D & $\begin{array}{l}\text { The effect of concern about reported income on } \\
\text { discretionary spending decisions: The case of } \\
\text { research and development. } \\
\text { Institutional monitoring and opportunistic earnings } \\
\text { management. } \\
\text { Earnings management around research and } \\
\text { development manipulation. } \\
\text { Managerial Overconfidence, Research and } \\
\text { Development, and Earnings Management: } \\
\text { Perspective from Capitalization and Expense. }\end{array}$ & $\begin{array}{l}\text { Baber et al., } 1991 \\
\text { Chung et al., } 2002 \\
\text { Guidara \& Boujelbene, } \\
\text { 2014 } \\
\text { Zhou et al., } 2020\end{array}$ \\
\hline $\begin{array}{l}\text { Intellectual } \\
\text { capital }\end{array}$ & $\begin{array}{l}\text { An accounting perspective on intellectual capital. } \\
\text { The effect of audit committee characteristics on } \\
\text { intellectual capital disclosure. } \\
\text { Do accruals earnings management constraints and } \\
\text { intellectual capital efficiency trigger asymmetric cost } \\
\text { behaviour? }\end{array}$ & $\begin{array}{l}\text { Lev et al, } 2005 \\
\text { Li et al., } 2012 \\
\text { Yang, } 2019\end{array}$ \\
\hline $\begin{array}{l}\text { Social \& } \\
\text { Environmental } \\
\text { incentives }\end{array}$ & $\begin{array}{l}\text { The relationship between corporate social } \\
\text { responsibility and earnings management: An } \\
\text { exploratory study. } \\
\text { Corporate social responsibility and earnings } \\
\text { management: Evidence from Asian economies. } \\
\text { Environmental Initiatives and Earnings Management } \\
\text { Corporate social responsibility and earnings } \\
\text { management in US banks. } \\
\text { Investigating the relationship between corporate } \\
\text { social responsibility and earnings management: } \\
\text { Evidence from Spain. } \\
\text { Corporate environmental disclosure and earning } \\
\text { management. } \\
\text { Do dimensions of corporate social responsibility } \\
\text { affect earnings management? } \\
\text { Corporate social responsibility and earnings } \\
\text { management of South African companies. }\end{array}$ & $\begin{array}{l}\text { Hong \& Andersen, } 2011 . \\
\text { Scholtens \& Kang, } 2013 \\
\text { Litt et al., } 2014 \\
\text { Grougiou et al., } 2014 \\
\text { Gras-Gil et al., } 2016 \\
\text { Brahmana, } 2018 \\
\text { Amar \& Chakroun, } 2018 \\
\text { Jordaan et al., } 2018\end{array}$ \\
\hline
\end{tabular}


Disclosure of companies' environmental information has quickly become an essential part of earnings management (EM). The environment represents a sub-analysed category. Social and ecological responsibility is receiving increasing attention from regulators, market participants, the public and the media [16]. Environmental incentives are part of a broader concept of corporate social responsibility, which is subject to closer scrutiny. This trend is undoubtedly expected in recent corporate ecological disasters, such as the British Petroleum oil spill. Accountability and transparency and to assist capital market participants in making more informed economic decisions. The Securities and Exchange Commission has issued its initiatives on the clarity of environmental disclosures [17].

Such disclosure initiatives underline the unprecedented growth of socially and environmentally responsible areas [18]. Many parties, meanwhile, are concerned about environmental issues. A study by Brahmana \& Tank [19] examined the relationship between the disclosure of environmental information by companies and EM. The main focus was on 238 publicly traded companies in three different industries, namely construction, technology and trade.

Table 1 lists the individual categories which we dealt with the most in the analytical part and at the same time we supported them with the literature in which the category is developed.

\section{Methodology}

First of all, classical analytical tools were used to collect knowledge from individually selected categories. We focused only on publications published in renowned databases Web of Science, or Scopus. Subsequently, we created Table 1, where the individual publications are mentioned. In the practical part, we focused on data collection through a questionnaire, and we managed to obtain a total of answers from 172 companies from various sectors. The overall return was $20.0 \%$. The particular questions concerned the subcategories of savings (S1, S2), investment (P1, P2), R\&D (R \& D1, R \& D2), Intellectual Capital (HC1, HC2, HC3, HC4), Social \& Environmental responsibility (E1, E2). The revolutions were designed to construct importance-performance analysis taking into account the conditions associated with COVID-19. The construction of the questionnaire involved scale answers focused on the importance, where respondents could choose the values 1 (less important) 4 (more important) and also performance (1 less performance) - 4 (more performance).

\section{Results and Discussion}

For constructing the importance-performance analysis, it was necessary to create the basic questions. These were the questions listed in Table 2, and the respondents subsequently answered using scale answers from 1 to 4 . In total, we present 172 answers from companies that decided to cooperate with our research. At the same time, we wanted to point out the current situation where companies have to operate in a restricted mode due to the Coronavirus (COVID-19) and have to prepare for the second wave, which should come at the end of 2020. The aim was to identify the impact on earnings management. 
Table 2. Research questions

\begin{tabular}{|l|c|l|}
\hline \multicolumn{1}{|c|}{ Dimension } & Item & \multicolumn{1}{c|}{ Question } \\
\hline Savings & S1 & Company creates savings account \\
\hline $\begin{array}{l}\text { Project } \\
\text { investment }\end{array}$ & S2 & Company focuses on energy savings \\
\hline P1 & P2 & $\begin{array}{l}\text { Company participates on projects from ITMS } \\
\text { entities to achieve success }\end{array}$ \\
\hline $\begin{array}{l}\text { Research \& } \\
\text { development }\end{array}$ & $\begin{array}{l}\text { R\& } \\
\text { D1 } \\
\text { R\& } \\
\text { D2 }\end{array}$ & $\begin{array}{l}\text { Company develops new device/principle/method/ } \\
\text { Company works on own infrastructure }\end{array}$ \\
\hline Human capital & HC1 & Company ensures for employees' education \& courses \\
\hline & HC2 & Company participates on conferences \\
\hline & HC3 & $\begin{array}{l}\text { Company has an own library or provides for employees' } \\
\text { books/manuals/research publications etc. }\end{array}$ \\
\hline & HC4 & Company creates the best working environment for employees \\
\hline Environment & E1 & Company takes a part in voluntary donation \\
\hline & E2 & Company has and develops own waste management \\
\hline
\end{tabular}

Figure 1 shows the importance-performance analysis, and the individual abbreviations are explained in Table 2 .

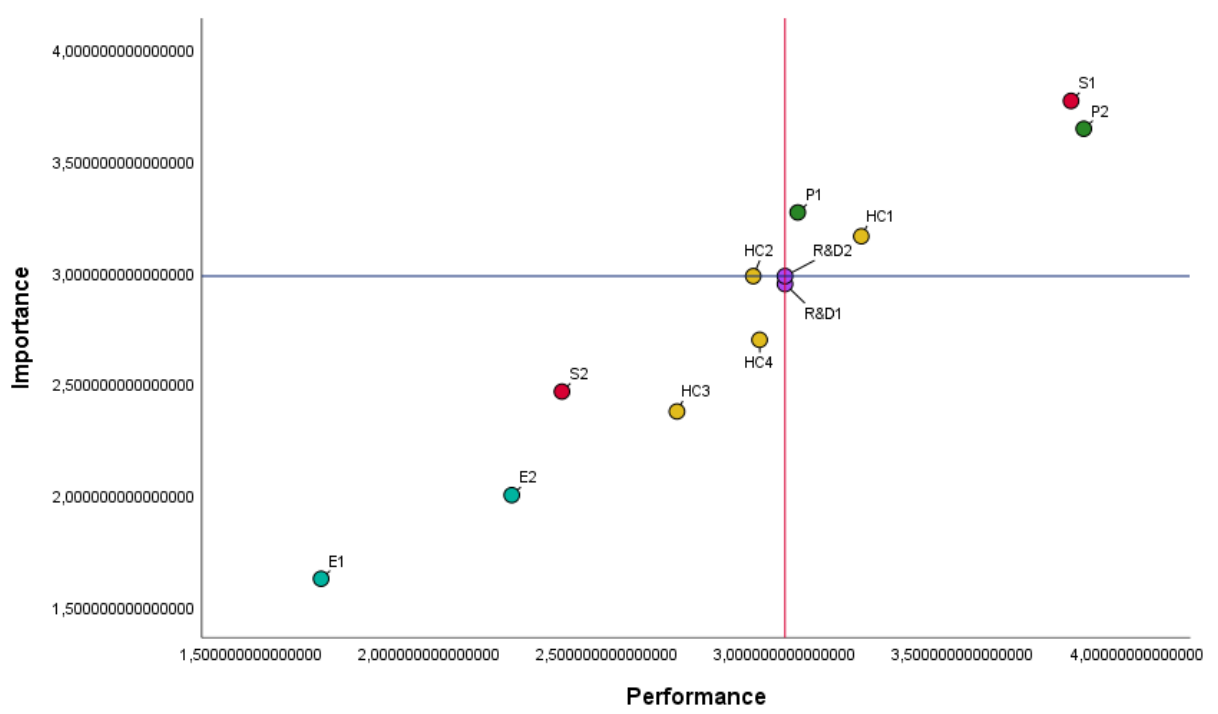

Fig. 1. IPA for incentives of earnings management.

Based on the importance-performance analysis, it has the highest importance and performance savings accounts and corporate projects. These are the biggest preconditions for the direction of earnings management in the future under current conditions. Some companies are considering possibly having diluted savings accounts even for cases of more difficult periods. Others are determined to do business and implement their projects despite the measures. However, they change from week to week, so it is necessary to monitor the changes continually and whether they affect the business activities of the company. Research and development, as well as intellectual capital, have been of medium importance 
and performance. The lowest level of significance and performance is for companies within earning management social \& environmental aspects.

\section{Conclusions}

The pandemic disease, which has been spreading in Slovakia since about March, is associated with a partial or complete restriction of the company's operations, which has an impact on reducing revenues, profits and generating fixed costs, a substantial reduction in cash flow. This may, in turn, lead to a decline in the company's market capitalization and have an impact on the company's shareholders. Threats of third-party liability claims against companies and management in connection with possible negligence of protection of customers, visitors and employees who may be disproportionately exposed to the coronavirus threat. Increased disinfection costs and various cyber threats such as fraudulent coronavirus e-mails.

Other hazards to which companies are exposed are credit risk, or a reduction in the turnover time of receivables, or unpaid receivables. Another wave of this disease is expected in autumn and winter, which should be much more threatening for Slovakia. Therefore, we decided to address the issue of earnings management. Based on our results, companies will primarily resort to creating a certain reserve in the form of a savings account. Generating savings makes it easier for a corporation to bargain with more critical conditions and thus evade bankruptcy. However, if the opportunity will not let their projects lie down, and they will seek realization.

This paper was supported by the Slovak Research and Development Agency under Grant number APVV-17-0546: Variant Comprehensive Model of Earnings Management in Conditions of the Slovak Republic as an Essential Instrument of Market Uncertainty Reduction.

\section{References}

1. Fielden, A., Michalkova, L., Vrbka, J., Lyakina, M. (2019). Smart Sustainable Datadriven Manufacturing: Cyber-Physical Production Systems and Internet of Things Sensing Networks. Journal of Self-Governance and Management Economics, 7(4), 713.

2. Kliestik, T., Valaskova, K., Lazaroiu, G., Kovacova, M., Vrbka, J. (2020). Remaining Financially Healthy and Competitive: The Role of Financial Predictors. Journal of Competitiveness, 12(1), 74.

3. Valaskova, K., Durana, P., Adamko, P., Jaros, J. (2020). Financial Compass for Slovak Enterprises: Modeling Economic Stability of Agricultural Entities. Journal of Risk and Financial Management, 13(5), 92.

4. Svabova, L., Kramarova, K., Chutka, J., Strakova, L. (2020). Detecting earnings manipulation and fraudulent financial reporting in Slovakia. Oeconomia Copernicana, 11(3), 485-508.

5. Tvaronavičienè, M., Masood, O., Javaria, K. (2018). Preconditions of the Eurozone economic security: how to overcome liquidity risk and cost inefficiency in leading banks of UK and Germany. Polish Journal of Management Studies, 18(1), 418-427.

6. Khan, K.A., Çera, G., Netek, V. (2019). Perception of the selected business environment aspects by service firms. Journal of Tourism and Services, 10(19), 111127. 
7. Nuryaman, Kartadjumena, E., Arnan, S. G. (2019). The influence of intellectual capital on earnings management through real activities manipulation in Indonesian manufacturing companies. International Journal of Economics and Business Research, 18(3), 277-291.

8. El Mir, A., Seboui, S. (2005). Stratégies d'innovation, diversification et gestion des résultats. La Revue des Sciences de Gestion, 40(216), 85-100.

9. Jensen, M. C. (1993). The modern industrial revolution, exit, and the failure of internal control systems. the Journal of Finance, 48(3), 831-880.

10. Affes, H., Chouaibi, J. (2007). La latitude managériale des dirigeants face à l'innovation technologique: Une analyse empirique sur le marché tunisien. Revue Gouvernance, 4(2), 1-14.

11. Guidara, R., Boujelbene, Y. (2014). Earnings management around research and development manipulation. International Journal of Academic Research in Accounting, Finance and Management Sciences, 4(2), 30-41.

12. Seetharaman, A., Sooria, H. H. B. Z., Saravanan, A. S. (2002). Intellectual capital accounting and reporting in the knowledge economy. Journal of Intellectual capital, 3(2), 128-148.

13. Roos, J., Edvinsson, L., Dragonetti, N. C. (1997). Intellectual capital: Navigating the new business landscape. Springer.

14. Bracinikova, V., Matusinska, K. (2018). Corporate Image of Banks From the Generation Y Perspective. Acta Universitatis Agriculturae et Silviculturae Mendelianae Brunensis, 66(2), 441-451.

15. Darabi, R., Rad, S. K., Heidaribali, H. (2012). The impact of intellectual capital on financial reporting quality: an evidence from Tehran Stock Exchange. International Journal of Business and Commerce, 1(11), 21-39.

16. SIF, U. (2012). Report on sustainable and responsible investing trends in the United States. US SIF.

17. Commodity, U.S. (2010). Futures Trading Commission and US Securities \& Exchange Commission. Findings regarding the market events of May 6 .

18. Litt, B., Sharma, D., Sharma, V. (2014). Environmental initiatives and earnings management. Managerial Auditing Journal, 29(1), 76-106

19. Brahmana, R.K., Tan, M.Y., You, H.W. (2018). Corporate environmental disclosure and earning management. International Journal of Green Economics, 12(3-4), 308321. 